\title{
The Attitude of Users towards a Micro Library "Gasibu": an Extended Service of Public Library in Sports Area
}

\author{
Neneng Komariah \\ Department of Library Information Science \\ Padjadjaran University \\ Syarif Hidayatullah State Islamic University \\ Jakarta, Indonesia \\ neneng.komariah@unpad.ac.id
}

\author{
Pawit M. Yusup \\ Department of Library Information \\ Science Padjadjaran University \\ Syarif Hidayatullah State Islamic \\ University Jakarta, Indonesia \\ pawitmy@gmail.com2
}

\author{
Encang Saepudin \\ Department of Library Information \\ Science Padjadjaran University \\ Syarif Hidayatullah State Islamic \\ University Jakarta, Indonesia \\ encang@unpad.ac.id
}

\begin{abstract}
The literacy movement should be supported by availability of qualified and access able reading materials for people with reading interest. The Public library may support literacy movement, by way of library empowerment. The Government of the West Java Province has built Gasibu public library, a micro library located near Gasibu sports area in Bandung. Objectives of this study was to find out the utilization of Gasibu micro library and the community's attitude toward the library. It used the survey research method and data were collected through interviews, questionnaires, and literature reviews. The study results indicated, utilization of Gasibu library was good, due to its location around the sports area, the library users were people with reading hobby and most of them were students. They visited the library to spend their spare time. The library users attitude was positive, based on cognitive, affective, and behavioral aspects. Thus, the Gasibu library supports literacy movement by providing access to library collections especially for students with reading interest. Recommendation: the library must improve its services to maintain the actual users as valuable assets of the library.
\end{abstract}

Keywords-Public Library; Gasibu Library; Dispusipda West Java Province; Literacy Movement.

\section{INTRODUCTION}

Currently, literacy becomes the focus of interest of people. The government, schools, and those who are supporting literacy campaigns are talking about the importance of literacy. Due to this, the government has launched the School Literacy Campaign (Gerakan Literasi Sekolah/ GLS) which is a program for all secondary school students who must read books together assisted by a teacher before starting to study in the classroom.

Awareness of the importance of literacy has been proclaimed by the government, especially for the West Java Province it is a very strategic step as the level of literacy of the Indonesian society is considered still very low. According to the Sindo newspaper (published May 8, 2016) the results of a research conducted by the Central Connecticut State University, in March 2016 showed that the level of literacy of the Indonesian society is still very low. Indonesia is in position 60 out of 61 countries with the best literacy level [1]. The news illustrates that reading interest in this case reading books of the Indonesian society is still low. Actually, the society in general is already aware that reading activity is the first step to make an individual becomes intelligent and knowledgeable.

Furthermore, there are various factors behind the reason why a person does not like reading books. Among them is the cultural factor which assumes Indonesians prefer to speak rather than read and write, hence causing a person unusual to read. Next is the family factor which does not teach early reading habits. Besides, the presence of the Internet is also blamed as a factor causing the community, especially children and young people, become lazy to read books as by browsing the Internet, they can easily acquire various desirable information for both learning and recreational purposes.

Sutarno explained that efforts to create reading habits from an early age will be successful if followed by the availability of interesting reading materials both in terms of the physical appearance of the book and its contents. [2] So, the growing interest in reading will become a reading habit, if children can get reading materials that catch their interest easily. The reading habit can be used as a foundation for the development of reading culture.

The availability of reading materials is an important factor in creating interest, customs and reading culture. Not all families in Indonesia are capable of providing adequate reading materials for their children as an effort to foster interest in reading. For school-aged children, school-reading materials are available in the school library. However, for those who are not attending school for various reasons, it is difficult to obtain adequate reading materials. Families from upper or middle-class economic levels will be able to buy books as family reading materials at home. On the other hand, for people from the middle to lower class level, it is very difficult to do so.

Actually, people can obtain various good reading materials in the form of books, magazines, encyclopedias, etc. in public libraries which are available in the neighborhood. Public libraries are libraries organized with public funds for the purpose of serving the public. The general library functions are: (1) open to the public. It means open to anyone regardless of gender, religion, faith, race, age, political and occupational views; (2) funded by public funds, 
that is funds originating from communities collected through tax and managed by the government; and (3) the services provided are essentially free [3].

Thus, the community has a place that can be visited which provides reading materials for free. In the library, a collection of available reading materials consisting of reading materials has been selected, arranged systematically to make it is easy to find, and the library staff who are ready to assist when visitors encounter some difficulties.

Public libraries can be found in almost every corner of the city in Indonesia. Even in the rural areas village libraries are available. According to the Minister of Education and Culture (Mendikbud) in the era 2014-2016, Anies Baswedan stated that "the library as a supporting infrastructure of reading habit in Indonesia is better than in Germany, South Korea, New Zealand and other countries in Europe" [1]. Nevertheless, the level of literacy of the Indonesian society is still low, whereas many public libraries are only visited by a small number of users.

One of the factors that make people reluctant to come to the public library is the distance of its location which may be far away from their residence. Another factor is the accessibility to the public library, since it is not passed by public transportation. Therefore, ideally the location of public libraries should be close to the settlements and easily accessible to the public. Alternatively, public libraries are established around community centers such as malls, sports venues, or car free day locations.

In Bandung city there are several public libraries that can be utilized by the community. There are public libraries owned by the government, as well as libraries managed by the community (private). Some public libraries managed by the community (non government) are House of Sunda Book Reading , Сири Manik Library, Pitimoss Library, Zoe Corner \& Library, Reading Light, Kuncen Bandung Library, etc. The public library owned by the government is the Library and Archives of Bandung and Bapusipda West Java Province. There is also the Gedung Merdeka Library which is a public library owned by the government and managed by the Museum of Asian-African Conference. The libraries are open to the public and provide a collection of reading materials with diverse subjects. The libraries are scattered in the city of Bandung with all the advantages and disadvantages.

In September 2016, one more public library was established in Bandung near Lapangan Gasibu and is thus named as its location Gasibu Library. This is a small library or popularly known as a micro library that attract enough attention of the community, due to its location on the edge of the Lapangan Gasibu which is the center of the community sports activities and is one of the icons of Bandung. Especially on Sundays and on public holidays the Taman Gasibu is usually crowded by people who exercise. Now, after the exercise, people can visit the Gasibu library.

Gasibu Library was built as a result of the partnership between the West Java Provincial Government and West Java Regional Library and Archives with Bank BJB. It is considered extraordinary because the West Java Provincial
Government has built a new micro public library as an effort to bring reading materials to the community in supporting literacy movement. On the other hand, it is also very interesting because Bank BJB has chosen the library as the target of its Corporate Social Responsibility (CSR) program. Whereas industries are usually more interested in providing scholarships, or strengthening the economic sector and environmental maintenance as its CSR target.

This paper will present the results of a study on the utilization of Gasibu Library as a mini public library (microlibrary) and the attitudes of library users (pemustaka) towards the library.

\section{METHOD}

The study used the survey method which take the sample from a population and use the questionnaire as the main tool for data collection [4]. The data collection techniques used were interviews to library managers and those who were related to this study, questionnaire to users of the Gasibu Library as the respondents, and literature study. The number of respondent was 100 people who used Gasibu Library. The study was conducted from January to April 2017.

\section{RESULT AND DISCUSSION}

Gasibu Library is open every Monday to Friday from 9:00 a.m to 18:00 p.m. Every Saturday from 9:00 a.m to 16.00 p.m. Every Sunday from 6.00 a.m to 12:00 p.m. Based on information from the library staff responsible in the service section, on Monday - Friday or work days. There was an average of 150 visitors a day and on holidays (Saturday and Sunday) there were 300 visitors.

There are no special requirements for using the library collections. Everyone from children to the elderly may read the collections of books in the library, but only to read it on the spot. Thus, the library does not lend books, therefore Gasibu library users do not require a membership card. If a visitor wants to borrow a book from the collection, then he/she is suggested to come to the DISPUSIPDA Library on Jl. Kawaluyaan Bandung.

Furthermore, in the Gasibu Library visitors are free to choose books that they will read. They can read while sitting in chairs that have been provided by the library. The layout of the bookshelves is quite loose so that visitors can move freely. Additionally, the placement of seats close to the bookshelves also facilitates visitors who want to see the contents of the book while seated. For visitors who want to read more seriously, chairs are provided a little further from the bookshelf, so that the reader can be more comfortable and more focused.

In addition, the outdoors arrangement of Gasibu Library makes visitors feel comfortable. The location of the library on the second floor with the entrance overlooking the Gasibu Field makes the view in front of the library very picturesque. The Gasibu field is overflown with unique jogging tracks and has made the location in front of the library a favorite place for people to take "selfies". Due to this, people are 
attracted to visit the Gasibu Library, and finally, are interested to enter the library. This proves that public libraries should be located in places where people often carry out activities so that they will attract attention (eye catching) and make people interested to enter the library. Once they are inside the library, they probably will be interested to look around and read the book that interests them.

Moreover, entering the Gasibu Library visitors should take off their shoes or sandals. This unusual situation is needed in order to maintain cleanliness and comfort in the library. However, the safety of shoes or sandals is guaranteed because they are stored on the provided shelves At the front room (lobby) of Gasibu library, all visitors are requested to fill in the quest-book which is available on a table with complete personal data such as name, address, and occupation. Behind the counter are two library staff ready to answer questions of visitors. In this lobby visitors must put their bags and/ or jackets in the locker that has been provided.

Based on the aspect of library service, the management of Gasibu Library is rather different. As library collections could not be borrowed, this caused visitors were unable to read in full to obtain complete information from the books they were reading. Moreover, most of the available books were quite thick which would take a long time to catch the information.

The day-to-day management of Gasibu Library is under the authority of DISPUSIPDA Jawa Barat, under the Division of Library Automation Service and Archives Service. Collections management activities such as recording books, which will be library collections, in the ledger book, classifying numbers of books, making labels and bar codes until the book is ready for display on the shelf and used by library visitors, all are conducted at DISPUSIPDA. DISPUSIPDA also provides staff in charge of managing the Gasibu library. Every day there are two DISPUSIPDA staff who are in charge of the Gasibu library. The staff take turns every week.

The Gasibu Library has 5000 titles of book collections consisting of general books, religions, social sciences, etc. It also provides re creative reading collections such as novels and picture books, as well as audio-visual books for children. The collection of books for children, adolescents and adult are stored separately in different shelves. This is in accordance with the prevailing rules of the public library that library collections should be kept separately according to the age group of library visitors. This is one of the characteristics of public libraries which should serve the community as a whole, hence public library managers should strive to make it easy for library users to find the books they need.

The library users visit the library eager to choose books that were available in the collection. When they found a title that interests them, they would read it while sitting in the available chairs or sofas. While for children, parents could pick and collect books and guide them to read. The situation was very exciting, seeing people who came enthusiastically to the library and read the provided collection of books. This was an asset that must be maintained so they would always have an interest in reading and become life-long learning society.

Moreover, there are eight computer units that function as OPAC (online public access catalog) to browse the collection of Gasibu library, and also the collection available at DISPUSIPDA library. There is also Wi-Fi facility to access the internet for free. Based on direct observations conducted by researchers, there were some students who brought their own laptop and used Wi-Fi to access the internet.

Based on the demographic characteristics, Gasibu Library visitors were mostly female, almost half of them were aged between 13-18 years, most of them were still in school. This indicated that Gasibu library played a role in supporting the needs of information sources of people who were in formal education. So, Gasibu library was an alternative library for students who needed information especially re creative information.

Furthermore, the users profile as respondents based on reading habits showed that generally they had reading hobby or reading habit. Due to this, the existence of Gasibu Library supported the community's need for reading material. Those who already had reading habit were an asset that must be maintained so that their reading habits were not lost again.

According to the library use pattern, it explained that all respondents had visited the library before and most of them visited the school library. This showed that the school library was the first library known by the community. In the period of their formal education, they would get reading materials from the school library. However, if they were no longer studying in school, they should look for free reading materials to meet their reading hobby by themselves. Thus, here was the role of public libraries as well as Gasibu Library which provided reading materials for the general public to support their reading interests.

The profile of the users of Gasibu library described that almost half of the respondents visited the Gasibu Library for the first time. This was obvious since the Gasibu Library has only been opened to the public in September 2016, so it was only about three months after its opening. (Data collection through the questionnaire was conducted in January 2017).

Furthermore, regarding the first source of information about Gasibu library, almost half of the respondents knew about the existence of Gasibu Library by themselves while exercising. This showed that they visited the library because of their own desire driven by curiosity and because they wanted to obtain reading materials, considering that generally respondents have reading hobby.

The reason most of the respondents visited the Gasibu Library for spending their spare time, showed that they visited because they had spare time. In other words, if they were busy, they would not visit the library. This situation was relatively good enough. Apparently not everyone went to the mall in their spare time. Hence, Gasibu Library should be developed to attract more people to visit it. Generally, respondents visited Gasibu Library with the purpose to read 
books. This proved that indeed, they had reading hobby and this hobby should be sustained by providing quality reading materials that interested them. Therefore, the existence of public libraries which are easily accessible by the community is a must.

To know the attitude of users towards the Gasibu Library, the study used attitude measurement with reference to the attitude measurement scale formulated by Saifuddin Anwar [5]. The respondents were given a questionnaire with several questions that could describe the aspects of cognition, affection, and behaviour.

The questions in the questionnaire used Likert scale with alternative answers such as, strongly agree, agree, no opinion, disagree, and strongly disagree. The answer measurement criteria started from $20 \%$ because the researcher used 5 categories. The smallest score was 1 and the largest score was 5. To determine the interval of each category, it was calculated and the result of the interval for each category was

16. The calculation results for categorization were:

$$
\begin{aligned}
& 20.00 \%-36.00 \%=\text { Very Low; } \\
& 36.01 \%-52.00 \%=\text { Low } \\
& 52.01 \%-68.00 \%=\text { Medium; } \\
& 68.01 \%-84.00 \%=\text { High } \\
& 84.01 \%-100.00 \%=\text { Very High }
\end{aligned}
$$

The first aspect of attitude was cognition, which was the respondent's knowledge about the Gasibu library. This aspect was represented in the opinion towards the suitability of the collection of books with the need (score 328), the diversity of book collections (score 378), and the ease of reaching the location of Gasibu Library (score 435). The results of the calculation showed that the percentage of answer scores was $76.07 \%$. This illustrated that the cognition aspect was in the high category. Thus, the users knowledge about the Gasibu Library was good.

The third aspect of attitudes was the behavioral aspect, which was the tendency to behave and in this case the tendency to behave in relation to the Gasibu Library. The behavioral aspect was represented in the opinion that there should be staff in the library room (score 412), interested in borrowing collections (score 370), interested to inform about Gasibu Library to friends or family (score 410), interested to revisit Gasibu Library ( 430). The result of the calculation showed the percentage of answer score was $81.10 \%$. This illustrated that the behaviour aspect was in the high category. Thus, the tendency of users behavior regarding Gasibu Library was good.

Overall it can be explained that library users already had a positive attitude towards the Gasibu library. They had good opinion, they were happy with the library, and they wanted to do good things related to Gasibu library, they would visit again the library and tell about the existence of the library to the people around them.

The users who already had a positive attitude was a very valuable asset for Gasibu library that should always be maintained. In the marketing context, getting new customers can cost five times greater than the costs involved in satisfying and retaining existing customers. [6]. Taking note of the statement, the Gasibu Library should always keep the users who had a positive attitude to remain loyal users, even might expect them to become supporters of the library, who would recommend to others to utilize the Gasibu library collections.

Recommendation in a marketing context is the strategy of word of mouth marketing; it is generally much more effective in influencing others than other promotional efforts such as advertisements in the mass media, brochures, etc. [7]. Therefore, Gasibu libraries should always strive to meet the information needs of actual users, so that they will become loyal supporters of the library.

In the endeavor keep the library users, the library should maintain the convenience of the library environment, improve the quality of service from library staff, improve the quality of library collections with the addition of new books or other collections. So, the users will always eagerly visit the library because they will always get new information or knowledge from the library.

In addition, it is essential that Gasibu Library should provide a means to communicate with the users. For example, the provision of a suggestion box for the users to convey their wish or complaint by writing it on a piece of paper and putting it into the suggestion box. Moreover, what is suggested by the users should be implemented by the library.

\section{IV.CONCLUSION}

Gasibu Library is a mini library (micro library) and is an extended service from the library of DISPUSIPDA West Java Province. The Gasibu Library only provides collection services for reading on the spot. Furthermore, building the Gasibu library is an appropriate step, as Bandung citizens eagerly visit and enthusiastically make use of the library collections, especially those who have reading hobby.

Moreover, Gasibu library plays a vital role in supporting the literacy movement that is being proclaimed by the government. Those who already have reading hobby can easily gain access to qualified reading materials which are provided free of charge. They are an asset of the nation that must be preserved. Therefore, the library should always improve the quality of its services in order to attract them to visit and develop their reading hobby to become independent lifelong learners.

The Gasibu Library is appropriately located in an area commonly visited by the public, which is on the edge of the sports field of Gasibu. Hence, library users know about the Gasibu library when exercising in the sports area. This shows that the selection of location of the library is a very important aspect to be considered because it will determine the success of library services.

Moreover, most of the library users are students. It means, the Gasibu library as a public library has been complementing the school library in supporting the community literacy movement. The presence of the Gasibu library enriches the reading materials available to the students.

The positive attitude of the users to the Gasibu library is a 
very valuable asset which the library should always retain,whereas keeping them will be more effective than promotional efforts for acquiring new users. In addition, those who have positive attitude are expected to become library supporters. Therefore, Gasibu library must always strive to meet their information needs, so that they will remain loyal users.

The success of the West Java Provincial Government which has cooperated with industry (Bank BJB) to build a public library (Gasibu library) could be an example for other provincial governments in Indonesia, or even in the ASEAN countries.

\section{REFERENCES}

[1] Neneng Zubaedah, "Pupuk Kebiasaan Membaca Sejak Dini," Seputar Indonesia, Bandung, p. 5, 08-Jun-2016.

[2] Sutarno NS, Perpustakaan dan Masyarakat. Jakarta: Sagung Seto, 2006.

[3] Sulistyo Basuki, Pengantar Ilmu Perpustakaan. Jakarta: Gramedia Pustaka, 1991.

[4] S. Effendi, Metode Penelitian Survai. Jakarta: LP3ES, 1995.

[5] Saifuddin Azwar, Sikap Manusia: Teori dan Pengukuran. Yogyakarta: Liberty, 2000.

[6] F. F. Reichheld, The Loyalty Effect. Boston: Harvard Bussiness School Press, 1996.

[7] Philip Kotler, Manajemen Pemasaran, Bahasa Ind. Jakarta: Indeks, 2007. 